NBER WORKING PAPER SERIES

ASSESSING THE ANTICOMPETITIVE EFFECTS OF MULTIPRODUCT PRICING

Dennis W. Carlton

Patrick Greenlee

Michael Waldman

Working Paper 14199

http://www.nber.org/papers/w14199

\author{
NATIONAL BUREAU OF ECONOMIC RESEARCH \\ 1050 Massachusetts Avenue \\ Cambridge, MA 02138 \\ July 2008
}

We thank James Dana, Dan O'Brien, Kevin Murphy, Russ Pittman, Alexander Raskovich, David Sibley, Laura Starling, and attendees at the 2008 International Industrial Organization Conference in Arlington, Virginia for useful comments. The views contained herein are the authors' and do not necessarily reflect the views of the U.S. Department of Justice. The views expressed herein are those of the author(s) and do not necessarily reflect the views of the National Bureau of Economic Research.

NBER working papers are circulated for discussion and comment purposes. They have not been peerreviewed or been subject to the review by the NBER Board of Directors that accompanies official NBER publications.

(C) 2008 by Dennis W. Carlton, Patrick Greenlee, and Michael Waldman. All rights reserved. Short sections of text, not to exceed two paragraphs, may be quoted without explicit permission provided that full credit, including $\odot$ notice, is given to the source. 
Assessing the Anticompetitive Effects of Multiproduct Pricing

Dennis W. Carlton, Patrick Greenlee, and Michael Waldman

NBER Working Paper No. 14199

July 2008

JEL No. L4

\section{ABSTRACT}

In response to the "standardless" approach used in LePage's v. 3M, the Antitrust Modernization Commission (AMC) and others advocate using a discount allocation approach to assess whether bundled loyalty discounts violate Section 2 of the Sherman Act. This approach treats loyalty discounts like predatory pricing. The analogy to predatory pricing is flawed. We propose an alternative approach that focuses on the presence of significant scale economies. We use our approach to analyze LePage's, as well as the recent PeaceHealth decision.

Dennis W. Carlton

Graduate School of Business

University of Chicago

5807 S. Woodlawn Ave.

Chicago, IL 60637

and NBER

dennis.carlton@chicagogsb.edu

Patrick Greenlee

U.S. Department of Justice

600 E Street NW Suite 10000

Washington, DC 20530

patrick.greenlee@usdoj.gov

\author{
Michael Waldman \\ Johnson Graduate School of Management \\ 323 Sage Hall \\ Cornell University \\ Ithaca, NY 14853-6301 \\ mw46@cornell.edu
}




\title{
ASSESSING THE ANTICOMPETITIVE EFFECTS OF MULTIPRODUCT PRICING
}

\author{
By DenNis W. CARlton, ${ }^{*}$ PAtrick GreEnleE, ${ }^{* *}$ AND MichaEl WALDMAN ${ }^{* * *}$
}

\section{INTRODUCTION}

Pricing strategies that link purchases of different goods and offer discounts present a challenge to antitrust. When do such approaches, like bundling, tying, and bundled loyalty discounts, represent price-cutting competition, and when are they tactics used to exclude rival firms and reduce competition? Given that such pricing plans often enhance consumer surplus and total welfare, per se condemnation is unwarranted. How then should courts identify cases that violate the antitrust laws?

Interest in this issue has recently increased following the decision in LePage's, Inc. et al. v. 3M Company. ${ }^{1}$ LePage's, a maker of invisible tape, prevailed against 3M's use of multiproduct discounts that linked invisible tape purchases to other product categories including healthcare, home improvement, and retail auto products. The Court of Appeals, however, was unclear about what features of 3M’s pricing strategy constituted exclusionary conduct. The decision has spawned much commentary, including an extended discussion in the Antitrust Modernization Commission’s (AMC) Report and Recommendations. ${ }^{2}$ Ongoing cases involving bundled discounts continue to

\footnotetext{
* Katherine Dusak Miller Professor of Economics, University of Chicago, Chicago, IL; Research Associate, National Bureau of Economic Research.

${ }^{* *}$ Economist, U.S. Department of Justice, Washington, DC.

${ }^{* * *}$ Charles H. Dyson Professor of Management and Professor of Economics, Cornell University, Ithaca, NY.

Authors' Note: We thank James Dana, Dan O'Brien, Kevin Murphy, Russ Pittman, Alexander Raskovich, David Sibley, Laura Starling, and attendees at the 2008 International Industrial Organization Conference in Arlington, Virginia for useful comments. The views contained herein are the authors' and do not necessarily reflect the views of the U.S. Department of Justice.

1 324 F.3d 141 ( $3^{\text {rd }}$ Cir. 2003).

2 Antitrust MODERNizATION COMMISSION, REPORT AND RECOMMENDATIONS (Apr. 2007), available at http://www.amc.gov/report_recommendation/toc/htm. Carlton served as a member of the AMC. For related literature, see for example, G. Hewitt, Loyalty and Fidelity Discounts and Rebates: Background Note, 5 OECD J. COMPetition L. \& PoL’y 143 (2003), Barry Nalebuff, Exclusionary Bundling, 119 ANTITRUST Bull. 159 (2005), Patrick Greenlee \& David Reitman, Distinguishing Competitive and Exclusionary Uses
} 
generate interest. In one such case, Cascade Health Solutions v. PeaceHealth, ${ }^{3}$ the Ninth Circuit took the unusual step of asking for views of interested parties before issuing its opinion. For that case, the Ninth Circuit recently certified a question to the Oregon Supreme Court about whether Oregon price discrimination law follows the requirements delineated by the U.S. Supreme Court in Brooke Group v. Brown \& Williamson Tobacco Corp. ${ }^{4}$ Some believe an appeal to the U.S. Supreme Court is likely after this question is answered.

In their report, the AMC advocates employing a discount allocation approach to assess the legality of bundled loyalty discounts. The approach interprets discounts offered on monopoly (or tying) goods as costs of providing the competitive (or tied) good. That is, the approach allocates the discounts provided on one product (or category of products) to the competitive product, and then asks whether the firm sold the latter good below cost. ${ }^{5}$ In essence, this applies the logic of predatory pricing to multiproduct discounts. To illustrate with an example, suppose a firm has a monopoly in product $A$ and faces competition in product $B$. Its constant marginal cost for $B$ is $\$ 5$, and consumers purchase up to one unit of each good. The monopolist offers the following loyalty discount: to customers that purchase my $B$ product at a price equal to $\$ 6$, the price for $A$ is only $\$ 10$, otherwise the price for $A$ is $\$ 12$. The $\$ 2$ discount offered on the monopoly product (\$12 $\$ 10$ ) is allocated as a cost for $B$, so the cost to offering $B$ is $\$ 7$ (\$5 production cost plus $\$ 2$ allocated discount). Since this $\$ 7$ cost for $B$ exceeds the price of $B(\$ 6)$, the monopolist

of Loyalty Discounts 119 AnTITRUST BuLL. 441 (2005), Roy T. Englert Jr., Defending the Result in LePage's v. 3M: A Response to Other Commentators, 119 ANTITRUST BuLL. 481 (2005), David Spector, Loyalty Rebates: An Assessment of Competitive Concerns and a Proposed Structured Rule of Reason, 1 COMPETITION POL’y INT’L 89 (2005), Bruce H. Kobayashi, The Economics of Loyalty Discounts and Antitrust Law in the United States, 1 Competition PoL'y InT’L 115 (2005), Alberto Heimler, Below Cost Pricing and Loyalty-inducing Discounts: Are they Restrictive and, if so, When? 1 COMPETITION POL'Y INT’L 149 (2005), and Daniel L. Rubinfeld, 3M’s Bundling Rebates: An Economic Perspective, 72 U. CHI. L. REV. 243 (2005).

${ }^{3} 05-35627$ D.C. No. CV-02-06032-ALH (9 $9^{\text {th }}$ Cir. 2007).

409 U.S. 209 (1993).

${ }^{5}$ This approach was previously advocated by the plaintiff in Ortho Diagnostics Sys., Inc. v. Abbott Lab, Inc. 920 F. Supp. 455 (1996), and has come to be known by many as the “Ortho test”. There is some imprecision across commentaries about what the test is, including which firm's costs are used for the test. 
flunks the discount allocation test. The argument is then that, because the firm flunks the discount allocation test, it must earn less by selling $B$, i.e., it could increase profits by selling just $A$ for $\$ 12$. But as we will show this is in fact not always the case.

While there is firm economic logic in single product predatory pricing cases behind the dual requirements of showing that the defendant priced below (some measure of) marginal cost and that it can recoup its losses, that same logic does not apply when price schedules link multiple products. A single product firm that prices every unit below marginal cost must have some motive other than short run profit maximization. Multiproduct firms, in contrast, may have several non-exclusionary motives such as price discrimination for adopting pricing plans in which some measure of price (after discounts have been allocated) is below some measure of cost. Firms that use such pricing plans for non-exclusionary rationales can fail an incremental cost test like that advocated by the AMC. Therefore, because the analogy to single product predation does not apply in more complex settings involving multiple goods or non-linear pricing, we reject the logic underlying the AMC type tests and instead focus on a test specifically framed to address the economics underlying exclusionary conduct.

A common ingredient in various economic theories that generate harmful exclusion is the presence of scale economies. While the economies do not have to apply specifically to production (meaning that they can relate, for example, to network externalities), harm arises in these theories typically when the dominant firm can deny scale to rivals and thereby diminish their ability to compete. Our approach to analyzing the anticompetitive effects of bundling focuses on establishing the existence of significant scale economies and the likely competitive effects that result from denying scale. Our approach allows us to generate a safe harbor that is relatively easy to implement. We also allow an efficiencies defense similar to that used in mergers.

Although our analysis reveals the drawbacks of a price cost test in a multi-product setting, we recognize the value of having clear safe harbors. Accordingly, we think it reasonable to have some price cost test such as the AMC test as a safe harbor though the imperfections of such a test must be recognized. Given our view that bundled discounts are generally procompetitive, we would tolerate the inability of a price cost test to detect all instances of anticompetitive exclusionary conduct. But the failure to fall into a price 
cost safe harbor should not lead to condemnation and legal liability since our analysis shows that non-exclusionary behavior can easily fail such tests. Using the economic theory that underlies most models of anticompetitive exclusion, we develop a series of tests for alternative safe harbors. For those who do not share our views on the desirability of price cost safe harbors in this setting, they should use our tests in place of, rather than in conjunction with, price cost tests.

This paper is organized in the following manner. Section II discusses various rationales for non-linear pricing strategies. It uses the single product case to establish a foundation, and then explores pricing strategies for firms that sell multiple products. Exclusionary and non-exclusionary rationales are discussed, as are the market conditions required for the various explanations to be plausible. Section III focuses on the approach recommended by the AMC to analyze bundled loyalty discounts, and discusses a number of its shortcomings. Section IV presents our analytic approach to multiproduct non-linear pricing focusing on scale effects. We conclude in Section V with an application of our approach to LePage's and PeaceHealth.

\section{Pricing Rationales}

In this section, we discuss competitive and potentially anticompetitive rationales for various pricing schemes. We start with the single product case, and then move to multiproduct pricing.

\section{A. Single product pricing}

Let us focus initially on the simplest type of single product pricing, namely uniform pricing. By uniform pricing we mean that the seller charges the same price for every unit sold, so that the total outlay function for any customer that purchases $q$ units is simply a line through the origin with slope equal to the price per unit $p: E(q)=p q$.

When might the level of a uniform price be used as a strategy to harm rivals and thereby reduce competition? An observed high unit price should not be condemned as anti-competitive, because high prices make it easier for rival firms to survive. ${ }^{6}$ Prices

\footnotetext{
${ }^{6}$ High prices are consistent with an absence of robust competition. If competition has been reduced in some manner, however, observed high prices are a symptom rather than a cause. A price in excess of a firm’s marginal cost but below rivals' marginal cost can be exclusionary. However, we believe it is prudent to
} 
below marginal cost, however, generate losses to the firm, at least in the short term. For such cases, it is natural to ask why the firm chooses to incur such losses. One possible anticompetitive motive is predatory pricing whereby the firm incurs short term losses in order to induce exit by rival firms, and then charge higher prices after competition has been eliminated. For such a strategy to be profitable, the predator firm correctly anticipates recouping its short term losses via higher prices in later periods. This generates the familiar legal requirements for pursuing a predatory pricing claimnamely, price below some measure of marginal cost and an ability to recoup short term losses via subsequent higher prices.

Some caution, however, is warranted in using this price/cost comparison as a test for anticompetitive behavior. Dynamic considerations, like learning by doing or consumer switching costs, may make it optimal for what looks like below cost pricing, even when a firm has no intent or ability to exclude. If production costs decline substantially with production experience, a firm may find it optimal to move quickly down its learning curve in order to exploit cost advantages sooner. Accomplishing this may require the firm to sell at prices below (its initially high) cost. Similarly, if consumers have high switching costs for a good, firms may find it optimal to sell initial units to new customers at a low price (perhaps equal to zero), and then sell later units at a much higher price. In these cases, pricing below some measure of cost can be viewed as making an investment today (in technology or consumer relationships) that generates returns tomorrow (due to cost advantages or consumer switching costs). It would be a mistake to condemn such strategies as anticompetitive. ${ }^{7}$

Let us turn now to non-linear pricing of a single product. A non-linear price schedule is any outlay function other than $E(q)=p q$. Perhaps the most common type of

presume any price that exceeds marginal cost is legal. To do otherwise runs the risk of dampening firms' incentives to set low prices or to innovate. See Brooke Group.

${ }^{7}$ Indeed, a correct calculation of marginal cost should include these dynamic considerations. See Andrew Dick, Learning by Doing and Dumping in the Semiconductor Industry, 34 J.L. \& ECON. 133 (1991), for an analysis of how learning by doing can lead to what looks like below marginal cost pricing in the absence of a predatory rationale. Paul Klemperer, Markets with Consumer Switching Costs, 102 Q.J. Econ. 375 (1987) shows a similar result for switching costs. 
non-linear price schedule is a quantity discount where the schedule offers lower unit prices for higher volume tiers. ${ }^{8}$

We can look for potentially troublesome pricing by comparing marginal revenue to marginal cost. We will soon see why a deviation from such pricing may be peculiar. As in the case of uniform pricing, if marginal revenue is well-defined throughout the price schedule and weakly exceeds marginal cost, then the pricing strategy should be presumed legal. ${ }^{9}$ What if marginal cost exceeds marginal revenue over some portion of the pricing schedule? This can be potentially problematic only if a large segment of consumers (measured in terms of total purchased volume) choose to purchase quantities that fall in these "potentially predatory" regions. ${ }^{10}$ Obviously, if all consumers purchase

\footnotetext{
${ }^{8}$ An all units discount is a pricing scheme that has the property that the price declines for every unit when a buyer reaches order size thresholds. For example, a customer may be charged \$10 per compact disc for orders that include less than 10 items, \$7 per compact disc for orders between 10 and 30 items, and \$4 per compact disc on orders that include more than 30 items. Since an order with 9 items costs $\$ 90$ and an order with 10 items costs only $\$ 70$, the incremental price for the 10 th item is $-\$ 20$. Given an order with 7 items, the seller offers a package of three additional items at zero additional cost.

${ }^{9}$ If the cost to supply a customer depends only on that customer's consumption, then an alternative approach would be to say that a price schedule is never predatory as long as, for all q, E(q) weakly exceeds the total variable cost of supplying q units. This is a less stringent test than the one in the text, and likely is easier to apply.

${ }^{10}$ For both smooth and discontinuous price schedules, “potentially predatory” regions consist of quantity ranges for which incremental cost exceeds incremental revenue. For an all-units discount, this typically occurs for a number of increments that include a discontinuity (at which price declines for every unit purchased). For the example presented supra note 8, there are several potentially predatory regions around each discontinuity in the price schedule. If the marginal cost for a CD is \$4, these include [7, 10], [10, 17], and [2, 32]. For the first of these examples, 6 units sell for $\$ 60$ and 10 units sell for $\$ 70$, so the incremental 4 units sell for an incremental $\$ 10$ which is below incremental cost $(4 \mathrm{x} \$ 4=\$ 16)$. For the last of these examples, 1 unit sells for \$10, 32 units sell for \$128, so the incremental 31 units cost an incremental \$118 which is less than cost (31 x \$4 =\$124). Which increment is relevant? This example was inspired by an actual clearance sale where most customers were likely to have a base quantity of zero absent the sale. Thus the relevant base quantity to consider is zero units. Provided marginal cost does not exceed \$4 for this example, there are no potentially predatory increments of the form [0, q], and thus none of these calculated potentially predatory increments is relevant. Alternatively, if the pricing scheme applies not to an individual but to a retailer and involves a product for which most retailers carry at least nine units of
} 
volumes that fall below the potentially problematic region, then the "potentially predatory” region has no effect. Alternatively, if all consumers purchase volumes that sufficiently exceed a "potentially predatory” region, then consumers make their purchasing decision based on an incremental price that exceeds incremental cost. ${ }^{11}$ Thus, the "potentially predatory” region again has no effect on competition. The only remaining case is if a large segment of consumers chooses to purchase quantities that fall in such a region. For this case, the inquiry then turns to assessing the effect that making these sales below incremental cost has on rivals. The total volume that shifts from a rival due to such a strategy will depend on how many consumers fall in this region of the price schedule, as well as how many additional units they purchase because price (marginal revenue) is below marginal cost. This incremental volume will depend on what the price for these units would have been but for the "potentially predatory" pricing schedule. While this will in general be hard to determine, we advocate assuming that the firm would price units at marginal cost. ${ }^{12}$ Only if the total shifted volume denies scale which induces exit or raises rivals' marginal costs should the pricing strategy be considered anticompetitive.

Firms may employ non-linear price schedules for reasons other than anticompetitive exclusion. First, economies of scale may make it less costly per unit for a firm to manufacture or deliver large quantities. In such cases, declining marginal revenue may arise because the relevant incremental cost is declining. For example, customers that purchase a full truckload of goods may enjoy a lower per unit price than a customer that purchases only half a truckload.

inventory, but could purchase as many as 15 to 17 units of this brand, then the increments starting at 10 may be relevant. Some of these are potentially predatory, so the inquiry would continue.

${ }^{11}$ In such cases, for a consumer contemplating whether to alter its purchase by one unit, the price for the marginal unit exceeds marginal cost. Alternatively, if the consumer decides between a purchase of $q$ units or no purchase at all, the price for the incremental $q$ units exceeds incremental costs if $q$ lies sufficiently outside a "potentially predatory” region. In both cases, the relevant "price” exceeds the relevant cost.

12 If the firm could not employ a price schedule with "potentially predatory” regions, it does not follow that competition would necessarily drive price down to marginal cost, especially if products are differentiated. Using marginal cost pricing as the benchmark makes it more difficult for a plaintiff to establish that a nonlinear pricing plan is exclusionary, but this benchmark also reduces the likelihood of making errors in which an uncompetitive firm prevails in court when it could not prevail in the marketplace. 
Second, when a single product monopolist is not perfectly informed about consumer preferences, it may employ a non-linear price schedule in order to sort potential customers by willingness to pay and thereby second degree price discriminate. A firm practices second degree price discrimination when it offers a price schedule that sorts consumer types based on their selections from the schedule. The firm designs the price schedule to simultaneously accomplish two goals: (1) offer each consumer type (or segment of consumers) a deal that they prefer over all others, and (2) extract as much value as possible from all consumers collectively. The monopolist's objective can be viewed as selecting the schedule (a collection of quantity-payment offers) that maximizes profit, subject to the constraints that each consumer type purchases the offer designed for it-namely, the consumer type prefers it over all other offers, and prefers it over the option of not making any purchase. ${ }^{13}$

Would a price discriminating monopolist ever employ a price schedule that has the property that over some range of output marginal cost exceeds marginal revenue? In general, the answer to this question is "no." When consumer preferences satisfy two technical properties, it has been established that marginal revenue in the monopolist's optimal price schedule strictly exceeds marginal cost for all quantity levels except the largest quantity sold. At the largest quantity sold, price equals marginal cost. ${ }^{14}$ That is,

\footnotetext{
${ }^{13}$ A standard assumption in models of this sort is that resale is not possible. Allowing the possibility of resale limits the ability of firms to price discriminate in these settings.

${ }^{14}$ The first technical property is that preferences satisfy what is called a "single crossing property": for any given pair of consumer types, one type always values an additional unit of the good more than the other type, regardless of the current quantity. The second technical property is that the distribution of types has an increasing hazard rate, i.e. if consumer type $v$ (where $v$ is the valuation) has density $f(v)$ and distribution $F(v)$, then $f(v) /[1-F(v)]$ is an increasing function of $v$. This latter condition is satisfied by many distributions including uniform, normal, and logistic. For greater detail, consult JEAN TIROLE, THE THEORY OF Industrial ORganiZation 142 (1988) or Eric Maskin \& John Riley, Monopoly with Incomplete Information, 15 RAND J. ECON. 171 (1984). If the firm employs a discontinuous price schedule so that marginal revenue is not everywhere well-defined, this condition holds wherever marginal revenue is well-defined.
}

The observation that marginal revenue should exceed marginal cost when a firm practices nonlinear pricing depends importantly on the information that the firm has about customers. In the example 
price is never below marginal cost in an optimal price schedule. If the price schedule is discontinuous, there may be increments for which incremental cost exceeds incremental revenue for volume levels near the discontinuity, but the slope of the outlay function (where the slope is well-defined) will exceed marginal cost. Thinking of marginal revenue as the price per unit for the next incremental unit, this says that in the continuous case a single product monopolist engaged in second degree price discrimination would have no regions in its price schedule where marginal cost exceeds marginal revenue.

\section{B. Multiproduct pricing}

Thus far, we have focused on pricing for a single good. In our discussion, a consumer's expenditure for that single good depended only on the quantity of that good purchased by the consumer. This condition can be relaxed in at least two ways: (1) when a firm sells multiple products, the outlay function need not be additively separable across goods, so that the charge for a given quantity of a firm's first good can depend on how many units of the firm's other goods are purchased at the same time, ${ }^{15}$ and (2) the price charged for a given quantity of a firm's good may depend on how many units of a rival firm's competing good are purchased in a given time period.

just discussed, the firm is assumed to know the distribution of consumer preferences but cannot distinguish amongst consumers, and so offers everyone the same nonlinear pricing schedule. With other assumptions about information, it might be possible to offer different price schedules to different consumers. In such cases it might be more complicated to determine whether the observed pricing is so inconsistent with profit maximization as to merit further inquiry. For example, suppose that there is a constant marginal cost of $\$ 7$, that consumer 1 has a willingness to pay of $\$ 10$ for one unit and zero thereafter, while consumer 2 has a willingness to pay of $\$ 8$ for the first unit, $\$ 8$ for the second unit and zero thereafter. A monopolist that can identify consumers and prevent resale will charge customer 1 \$10 for one unit, and customer 2 \$8 per unit for each of two units. The analyst will observe that one unit sells for $\$ 10$ while two units sell for $\$ 16$. It would be improper to calculate the incremental price of the second unit as $\$ 6$ ( $\$ 16-\$ 10)$ and conclude that something is unusual because $\$ 6$ is below the cost of $\$ 7$.

${ }^{15}$ The outlay function is additively separable if and only if the total outlay function can be expressed as a sum of single product outlay functions: $E\left(q_{1}, \ldots, q_{n}\right)=\sum E_{j}\left(q_{j}\right)$ for all purchase orders $\left(q_{1}, \ldots, q_{n}\right)$. If such a decomposition is not possible, then the pricing of at least one product is linked in some manner to the purchased quantities of other products. 
Bundles are examples of (1). The price of a beverage, for example, may depend on whether the consumer also purchases a main course and side dish to accompany the beverage.

Loyalty discounts and ties are examples of (2). Loyalty discounts provide benefits to customers that are sufficiently loyal to the supplier, where "loyalty" typically is measured as the fraction of all purchases in a product category that are made from the supplier. For example, in Concord Boat v. Brunswick Corp., boat builder Concord enjoyed a 3\% price reduction on every engine purchased from Brunswick provided Concord sourced at least $80 \%$ of its engine requirements from Brunswick. ${ }^{16}$ In such cases, the charge for eight Brunswick engines will depend on whether the boat builder purchased more than two engines from a rival supplier. Such loyalty requirements may also link across different products. These are often referred to as "bundled loyalty discounts." For example, the price an office supply store pays for 3M's Post-it notes may depend on the quantity of invisible tape purchased from 3M. In a tying strategy, a firm offers the tying good only to consumers that are $100 \%$ loyal in their purchases of the tied good. ${ }^{17}$ In such cases, one can interpret the "list" price for the tying good by itself as being so high that there is zero demand. Seen in this light, ties are a special case of bundled loyalty discounts, so a firm may use a loyalty discount as a de facto tying strategy. Because the economics of bundled pricing and tie-in sales are so closely related, their separate treatment under antitrust law is anomalous.

Before addressing tests for anticompetitive uses of non-linear pricing, which we consider in detail in the next two sections, we briefly discuss non-exclusionary and exclusionary motives for bundling and tying. ${ }^{18}$ Among the non-exclusionary motives for tying/bundling are (1) achieving efficiencies in production or selling, or improved

\footnotetext{
${ }^{16} 207$ F.3d 1039 (8 ${ }^{\text {th }}$ Cir. 2000).

${ }^{17}$ There are several definitions of tying. In some, the quantity of the tying good is variable while in other cases it need not be. The key point is that the same economic forces operate when a group of products are purchased and the price for that group of products depends on the underlying quantities of each purchased product, and perhaps on the quantities purchased from rival firms.

${ }^{18}$ For greater detail, consult Dennis W. Carlton \& Michael Waldman, Tying, in IssuES IN COMPETITION LAW AND POLICY (American Bar Association, forthcoming, 2007) and BARRY NALEBUfF, BundLING, TYing, AND PoRTFOlio EFFECTS (DTI Econ. Paper No. 1, 2003).
} 
product mix, (2) price discrimination, and (3) increasing product differentiation. Anticompetitive motives include (4) extending a monopoly from one product to another, and (5) enhancing existing market power or preserving a monopoly from potential entry.

\section{Achieving efficiencies}

When there are economies of scope or scale in the manufacture, selling, or delivery of products, bundling them together can allow the supplier to achieve efficiencies that lower its costs and prices paid by consumers. David S. Evans and Michael Salinger illustrate this effect via cold medicines that include multiple active ingredients, RadioShack packages that include electrical adapters for several countries, and the clustering of optional equipment for automobiles into a small number of packages. ${ }^{19}$ In these examples, the authors argue, the bundling reduces production costs, saves valuable retail shelf space, or reduces costs by simplifying production logistics.

Tying can preserve or improve quality by overcoming informational failures. When one product's performance relies on the quality of other products (either complements or inputs) but consumers cannot determine which component caused a performance failure, requiring the consumer to use only a single firm's components solves the blame game and preserves firm reputation. The single firm will have better incentives to provide high quality components than a firm that can blame, or partially blame, someone else. ${ }^{20}$ Roy W. Kenney and Benjamin Klein make a related argument in which bundling is used when it is difficult for consumers to ascertain quality, and pricing based on average quality is used to reduce transaction costs. ${ }^{21}$

Finally, tying can improve efficiency in variable proportions settings by eliminating distortions created by the presence of market power. For example, if a durable good provider is a monopolist but maintenance is competitively supplied,

\footnotetext{
${ }^{19}$ David S. Evans \& Michael Salinger, Why Do Firms Bundle and Tie? Evidence from Competitive Markets and Implications for Tying Law, 22 YALE J. REg. 37 (2005) and David S. Evans \& Michael Salinger, The Role of Cost in Determining when Firms Offer Bundles, 56 J. InDUs. ECON. 143 (2008).

${ }^{20}$ James D. Dana, Jr. \& Kathryn E. Spier, Bundling and Product Reputation (unpublished manuscript, available at http://www.economics.neu.edu/dana/papers/DanaSpierBundling.pdf, 2007) formally show how bundling can make it easier for a firm to offer high quality when consumers cannot tell which component failed. That is, bundling allows the firm to internalize a "reputation externality."

${ }^{21}$ Roy W. Kenney \& Benjamin Klein, The Economics of Block Booking, 26 J.L. \& Econ. 497 (1983).
} 
consumers will tend to consume too much maintenance because they will face a greater markup on equipment compared to service. Tying maintenance to the sale of durable units avoids the distortion. $^{22}$

Absent the presence of other anticompetitive effects, bundles and ties that increase efficiency by reducing costs, increasing quality, or reducing product mix distortions should be encouraged.

\section{Price discrimination}

A firm can use bundling/tying to price discriminate among its customers. This can happen in at least three ways. First, if a firm sells a durable good that requires a consumable (like photocopiers and toner), and consumers that place a high value on the services provided by a durable good also consume large amounts of the consumable, then a firm that ties the durable good to purchases of the consumable can charge different effective "system” prices to different types of consumers. This pricing strategy is referred to as metering. Compared to uniform monopoly pricing, the tie allows the firm to mark up its price of the consumable above the competitive level and lower the price for the durable good. $^{23}$

Second, if consumer valuations for two products generally are negatively correlated, so that individuals that really like a first product tend to dislike a second product, then valuations for the bundle (assuming there are no interaction effects when the two goods are consumed together) exhibit lower variance than the sum of the variances of the valuation of each product separately. In such cases, the optimal bundle price extracts a larger fraction of consumer surplus than does setting separate prices for each of the two goods. Intuitively, consumers that really like the first product assign a

\footnotetext{
${ }^{22}$ See Tirole, supra note 14, at 181 for a formal demonstration. Dennis W. CARLton \& MiCHAEL WAldman, Competition, Monopoly, AND Aftermarkets (NBER Working Paper No. 8086 revised, 2007) show how a similar result arises in competitive durable goods markets with switching costs.

${ }^{23}$ Note that this approach does not necessarily require the two goods to be complements. Provided that consumers with valuations for one good typically purchase large amounts of a second (perhaps unrelated) good, tying in order to meter can allow the firm to extract more rents than uniform pricing. See Zhiqi Chen \&Thomas Ross, Refusals to Deal, Price Discrimination, and Independent Service Organizations, $2 \mathrm{~J}$. Econ. \& Mgmt. Strategy 593 (1993) and Benjamin Klein, Market Power in Antitrust Economic Analysis After Kodak, 3 S. Cт. ECON. Rev. 43 (1993).
} 
large portion of the bundle price to the first good, while those that greatly prefer the second good view the bundle price as mostly applying to the second good. Seen in this light, the bundling firm effectively charges different prices for each good to different customers, i.e. it price discriminates. George J. Stigler suggests this motive for film owners that offer block booking to film exhibitors. ${ }^{24}$

Third, a firm can sort customers by offering various bundles at different prices, so that the firm captures more value (via higher prices) from consumers with high valuations. For example, many airlines bundle departing and return flights together and set different prices for various flight pairs in order to sort business travelers (who may have high willingness to pay) from vacationers (who may generally have greater flexibility and/or less willingness to pay). Itineraries with Saturday night stays, which often are sold to vacationers rather than business travelers, frequently are priced lower. To price discriminate in this fashion requires the seller to bundle the flights together because a seat on a Wednesday evening return flight might be occupied by a business traveler making a day trip, or by a vacationer completing a two week holiday.

Price discrimination is not by itself an antitrust violation because it need not have any anticompetitive effect on rivals (indeed there may not be any rivals). Therefore it should not be the basis for challenging a pricing strategy. ${ }^{25}$

\section{Increasing product differentiation}

Tying can increase product differentiation which can soften price competition. For example, a firm that ties a homogenous product $(B)$ to a monopoly product $(A)$ has differentiated its $B$ product. If the firm can commit to the tie, it commits not to compete aggressively for consumers that do not like the $A$ product. Rather than heated competition

\footnotetext{
${ }^{24}$ George J. Stigler, The Organization OF Industry 165 (1983). For additional discussion of a monopolist's use of bundles to price discriminate, consult R. Preston McAfee, John McMillan \& Michael D. Whinston, Multiproduct Monopoly, Commodity Bundling, and Correlation of Values, 104 Q.J. ECON. 371 (1989), W.J. Adams \& J.L. Yellen, Commodity Bundling and the Burden of Monopoly, 90 Q.J. Econ. 475 (1976), and Richard Schmalensee, Output and Welfare Implications of Monopolistic Third-Degree Price Discrimination, 71 AM. ECON. REV. 242 (1981).

${ }^{25}$ For further discussion, consult Dennis W. CArlton \& Ken Heyer, Appropriate Antitrust Policy TOWARDS SingLe FIRm Conduct (U.S. Dep’t of Justice Econ. Analysis Group Discussion Paper 08-02, 2008).
} 
between two firms offering homogenous products, tying introduces product (or bundle) differentiation and both firms may respond by raising price. ${ }^{26}$ This use of tying/bundling is a type of product positioning, akin to a cereal maker deciding how much sugar to include in each of its varieties. While it may result in higher prices, this use should not be the basis for a challenge when firms unilaterally adopt such a strategy for the usual reasons associated with concerns about unilateral decision making. If done collusively, such a tying strategy may be part of a market allocation scheme.

We now turn to anticompetitive uses of bundling/tying strategies.

\section{Monopolizing a second market}

The most frequently pursued anticompetitive claim for bundling/tying is that linking sales of two products allows a firm with significant market power in one product to extend or "leverage" its market power into other (currently) competitive markets. Such theories must overcome the "one monopoly rent" critique put forward by economists and attorneys affiliated with the University of Chicago. ${ }^{27}$ While tying to exclude in a second competitive market may be feasible for a monopolist, the one monopoly rent critique demonstrates that such tying often is not profitable, and therefore anticompetitive exclusion is unlikely to be the motive behind tying. A collection of subsequent papers has established the generality of the one monopoly rent critique, and has also established settings in which the critique does not apply, so that tying to exclude is feasible and profitable. $^{28}$

A key ingredient in most of the models that generate harmful tying in equilibrium is the presence of a scale economy. With these, tying allows the monopolist to profitably exclude a rival, or to profit from market segments it cannot reach with just its monopoly

\footnotetext{
${ }^{26}$ For economic analyses, consult Yongmin Chen, Equilibrium Product Bundling, 70 J. Bus. 85 (1997) and Jose Carbajo, David de Meza \& Daniel J. Seidmann, A Strategic Motivation for Commodity Bundling, 38 J. INDUS. ECON. 283 (1990).

${ }^{27}$ See, for example, Aaron Director \& Edward H. Levi, Law and the Future: Trade Regulation, 51 Nw. UnIV. L. Rev. 281 (1956), Ward S. Bowman, Tying Arrangements and the Leverage Problem, 67 Yale L.J. 19 (1957), Richard A. Posner, Antitrust Law, an Economic Perspective (1976), and Robert H. Bork, The Antitrust Paradox: A Policy at War With ITSElf (1978).

${ }^{28}$ See Michael D. Whinston, Tying, Foreclosure, and Exclusion, 80 AM. ECON. REV. 837 (1990), and the literature reviews by Carlton \& Waldman, supra note 18, and NALEBUFF, supra note 18.
} 
good. For example, Michael D. Whinston shows harmful tying in a complementary good setting when there are scale economies for the rival firm's production of the complementary good, and there are uses of the complementary good that do not require the monopoly good. In this setting, tying the competitive good to the monopoly good can deny necessary scale to the rival firm, leading the rival firm to exit, and allowing the monopolist to set higher prices for the complementary good. ${ }^{29}$ The monopolist profits from this tying because following exit it can earn greater profit from consumers that had no interest in its monopoly product.

Whinston and Barry Nalebuff each show similar results concerning independent products. ${ }^{30}$ In each case there are two independent products, a firm that is a monopolist in one market and which also sells the second product, and a potential rival that can enter the second market. In Whinston's version of this argument tying causes the incumbent to be a more aggressive competitor in setting the bundle price than when he sells individual products. The reason is that failure to sell the bundle deprives the monopolist of the profit on both products, so the monopolist has a greater incentive to sell when he bundles. This behavior lowers rival profits. The end result is that tying can reduce the rival's profit sufficiently that it decides not to enter because it is now unable to cover its fixed costs, and when this is the case tying can be optimal for the monopolist. ${ }^{31}$

The economy of scale can also take the form of an R\&D investment in a dynamic setting. For example, the rival firm can have constant returns to scale in a period but

\footnotetext{
${ }^{29}$ There need to be uses for the competitive good that do not depend on the monopoly good. Otherwise the value from the competitive good relies on the presence of the monopoly good, and the monopolist does just as well or better by not tying and setting the two prices appropriately. That is, if there are no separate uses for the competitive good in this setting, then the one monopoly rent critique is valid. For additional detail, see Whinston supra note 28, and Carlton \& Waldman supra note 18.

${ }^{30}$ See Whinston, supra note 28, and Barry Nalebuff, Bundling as an Entry Barrier, 119 Q.J. ECON. 159 (2004).

${ }^{31}$ Although there are important differences between Whinston's and Nalebuff's analyses such as that in Whinston's analysis the monopolist can commit to whether or not it ties while Nalebuff assumes no commitment, from our perspective the basic argument is the same. Tying can stop entry by making it infeasible for the rival to cover its fixed costs, and this increases monopoly profits because the firm becomes a monopolist in a second market.
} 
R\&D investments today can serve to lower marginal costs tomorrow. If tying by the monopolist serves to lower the rival's output, then the anticipation of such tying tomorrow can lower the rival's R\&D expenditure today and in this way increase the rival's marginal cost in subsequent periods. Similar to what was true in Whinston's complementary good analysis, this can increase monopoly profits in future sales to customers with no interest in the monopolized product.

\section{Enhancing existing market power or maintaining a monopoly}

When the two products are complements and rival firms have economies of scale, the dominant firm may tie in order to eliminate an inferior competing version of its primary good, or to deter subsequent entry by a complementary good provider into the primary good. A provider of an inferior version of the primary good may make no sales, but if not excluded can still have a competitive effect by constraining the price charged for the primary good. If there are scale economies in producing the complementary good such that tying induces all rival complementary good producers to exit, then tying induces exit by the rival primary good provider (because it does not have an independent source for the complementary good). This in turn allows the dominant firm to set higher prices for its primary good. This tying strategy is a way to increase the rival's costs of providing an alternative to consumers (by eliminating its sources for complementary goods). ${ }^{32}$

Dennis W. Carlton and Michael Waldman consider a dynamic setting in which an incumbent firm sells a primary good and a complementary good. ${ }^{33}$ In the first period, a potential entrant decides whether to enter and produce a superior complementary good. In the second period, the potential entrant decides whether to enter and produce the superior complementary good (if it has not already done so), and whether to enter and produce an identical primary good. When there are entry costs for each market, tying by the incumbent may deter entry (in the complementary good) in the first period by denying scale. If entry costs for the complementary good can only be covered by selling in both periods, tying in the first period may induce the potential entrant not to sell the

\footnotetext{
${ }^{32}$ For more detail and discussion, consult Whinston supra note 28, and Carlton \& Waldman supra note 22.

${ }^{33}$ Dennis W. Carlton \& Michael Waldman, The Strategic Use of Tying to Preserve and Create Market Power in Evolving Industries, 33 RAND J. ECON. 194 (2002).
} 
complementary good in either period. And given that it makes no complementary good sales, tying may cause entry into the primary good market to become unprofitable.

Summarizing our discussion of rationale (5), key ingredients to these theories of harm are (i) the products that are tied/bundled are complements, (ii) there are uses for the complementary goods other than with the dominant firm's primary good, ${ }^{34}$ and (iii) there are scale economies in producing the goods. If the linked products are not complements, then linking them cannot affect the profitability of participating in the primary good market. If there are no other uses for the complementary goods, then the one monopoly rent critique typically applies. And if there are no scale economies, then denying sales to a potential entrant does not diminish the competitive discipline offered by a potential entrant.

Taking rationales (4) and (5) together, these anticompetitive motives for bundling (monopolizing a second market, maintaining an existing one) share a common ingredient: the presence of significant scale economies. Under these theories of harm, the firm that links products via its pricing strategy denies scale sufficient to completely exclude its (potential or actual) rivals. Or said differently, the total sales opportunities that remain available to the rival firm(s) after the bundling strategy is employed will not cover the rival firm's fixed costs, so the rival exits or decides not to enter. If a non-linear pricing strategy denies sales to a rival, but the rival remains in business, the pricing strategy can damage competition only if the lost sales cause the rival firm's marginal cost to increase. Where scale economies exist, reducing scale raises average cost, but does not necessarily increase marginal cost. The approach we propose in Section IV emphasizes the role of

\footnotetext{
${ }^{34}$ In Carlton \& Waldman supra note 33, for example, the alternative use of the rival's complementary good is pairing it with the rival's primary good. Note that one exception is DENNIS W. CARLTON \& MiCHAEL WALDMAN, Tying, Upgrades, AND Switching Costs in DuRABLE GoOdS MARKETS (NBER Working Paper No. 11407 revised, 2006) where, even though exclusionary tying can be profitable, complementary goods can be used only with the dominant firm's primary good. In that explicitly dynamic model tying is not used to cause a rival to exit or increase its marginal cost, but rather to capture upgrade and switching cost profits that, due to the dynamic nature of the model, cannot be captured through optimal pricing of the monopolized product. For a related analysis, see Janusz Ordover \& Greg Shaffer, Exclusionary Discounts (unpublished manuscript, available at http://www.simon.rochester.edu/fac/shaffer/Published/two-unitsfullproof.pdf, 2007).
} 
scale economies. Before turning to that, we first use our analysis to discuss the price/cost test approach introduced in Ortho, advocated by the AMC, and recently employed in PeaceHealth.

\section{BUNDLED LOYALTY DISCOUNTS AND THE AMC RECOMMENDATION}

In its Report and Recommendations, the AMC advocates the following threeprong approach to determine whether bundled loyalty discounts that link pricing for a monopoly product to purchases of a competitive product violate Section 2 of the Sherman Act:

(1) If the loyalty program generates a total discount of $D$ for the monopoly product, allocate this discount to the competitive product and check whether the defendant firm sold the competitive product below its incremental cost (where the competitive good's price has been reduced, or its cost has been increased, to reflect the discount $D$ ). If the firm did not sell the competitive product below its incremental cost (calculated in this fashion), then there is not a violation.

(2) If the discounted-adjusted price is below cost, check whether the defendant is likely to recoup these short-term losses. If recoupment is unlikely, then again there is no violation.

(3) Finally, if price is below cost and recoupment is likely, check whether the loyalty program is likely to have "an adverse effect on competition."

This approach treats the offered discount as an opportunity cost, i.e. it implicitly assumes that the firm could have sold the monopoly good at the undiscounted price, but instead chose to offer the discount $D$. In other words, it implicitly assumes that the price for the monopoly good when sold separately is unaffected by the tie and that the number of units sold of the monopolized good is not significantly reduced when goods are sold separately. If the revenues collected for the competitive product do not exceed the costs of the competitive product plus the opportunity $\operatorname{cost} D$, then why has the firm offered such a program? Calculated in this manner, the firm makes incremental losses and would 
have earned more if it had sold only the monopoly product at the undiscounted price. That is, the loyalty program is noncompensatory. ${ }^{35}$

This price/cost test is a predatory pricing test. The main difference between this and the standard predatory pricing test is that instead of comparing a uniform price for a single good to some measure of its marginal cost, the test now focuses on one of multiple goods sold by the defendant firm, and allocates a discount earned on other product(s) to this one. While the logic behind such a test is straightforward for the single product case, a number of logical problems arise for the multiproduct case. ${ }^{36}$ The problem is that the logic underlying the AMC test ignores the incentive of a firm to use tie-ins or bundling as a method to price discriminate. Accordingly, the AMC test fails to be a sensible test when tie-ins and bundling are used to price discriminate.

First, a firm may set portions of a multiproduct non-linear pricing schedule with no intention of selling any units at such prices. Such prices may be set in a manner that allows the firm to price discriminate. For example, a firm could set a very high list price for one of its goods, and provide a substantial discount on this good only to consumers that purchased $100 \%$ of their requirements of a second good from that firm. If the firm would make no sales of the first good at the high list price, then this pricing strategy is de facto tying rather than predatory pricing and it is incorrect to view the discount offered on the first good as an opportunity cost. This point applies especially to loyalty programs that are designed for a specific consumer. In such cases, the consumer typically satisfies the loyalty requirement and receives the "discount," so no one pays the undiscounted "list" price. Recognizing this, the firm does not necessarily set the undiscounted price with the goal of selling any units at that price. Hence the discount should not be considered an opportunity cost.

Second, even when some sales occur at the list price, that price may not prevail absent the nonlinear pricing strategy. The reason again is that the firm may be using

\footnotetext{
${ }^{35}$ The compensatory price test terminology is due to Janusz A. Ordover \& Robert D. Willig, An Economic Definition of Predation: Pricing and Product Innovation, 91 Y ALE L.J. 8 (1981).

${ }^{36}$ When rival firms can assemble the entire the bundle themselves so that there is bundle-to-bundle competition (i.e. there is no monopoly good), the analysis of pricing is simplified to the standard predatory pricing approach where one treats the entire bundle as a single product.
} 
bundling to price discriminate. Indeed, having the same list price absent the nonlinear pricing strategy would be unlikely. ${ }^{37}$ If a different price would prevail, it is wrong to treat the discount $D$ as the relevant opportunity cost. In fact, given that $D$ is not necessarily the appropriate opportunity cost, a firm could flunk the AMC test yet not harm competition. For example, suppose that there are two consumers. One consumer is willing to pay $\$ 15$ for $A$ but places no value on $B$, while the second consumer values $A$ at $\$ 11$ and $B$ at $\$ 6$. Suppose $B$ is sold competitively for $\$ 5$, the constant marginal cost of producing $B$. The monopolist of $A$ will charge $\$ 11$ for $A$ when he sells only $A$, will sell 2 units, and will earn $\$ 22$ where, for simplicity, we assume that there are no costs to producing $A$. With (mixed) bundling, the monopolist of $A$ will charge $\$ 15$ for $A$ alone and $\$ 16$ for the bundle $(A, B)$, and earn $\$ 26$ (= $\$ 15+\$ 16-\$ 5) .{ }^{38}$ Notice how the stand-alone price for $A$ rises from $\$ 11$ to $\$ 15$ when the monopolist of $A$ uses mixed bundling. This pricing fails the first prong of the AMC test because the discount is $\$ 15+\$ 5$ - \$16 = \$4 and the marginal cost for $B$ is $\$ 5$, yielding a net cost of $\$ 9$ which exceeds the price of $B(\$ 5)$. Each consumer will buy from the monopolist and no firm that sells only $B$ will exist. Yet there is no competitive harm to consumers of $B$ since they continue to benefit from the competitive constraint on the price of $B$ of $\$ 5$ imposed by potential producers of $B .{ }^{39}$ (The

\footnotetext{
${ }^{37}$ Patrick Greenlee \& David Reitman, Competing with Loyalty Discounts (U.S. Dep’t of Justice EAG Discussion Paper 04-02, revised, available at http://www.wcas.northwestern.edu/csio/Conferences/Papers2006/GreenleeandReitmanpaper.pdf, 2006) present a differentiated single product duopoly model in which duopolists offer competing loyalty discounts, and find equilibrium results that are in the spirit of prong (1). That is, if a firm increases its loyalty program in a manner in which incremental cost exceeds incremental revenue, then the firm must have some goal other than short term profit maximization. Consistent with our discussion here, in their model there is a consumer segment that is only offered the list price (so some sales are made at the list price), and there is neither a monopoly nor a motive for price discrimination. For additional discussion, including how their analysis relates to Virgin Atlantic Airways Ltd. v. British Airways PLC [257 F.3d 256 ( $3^{\text {rd }}$ Cir. 2001); Case No. IV/D-2/34.780, Virgin/British Airways (1999)], consult Kobayashi supra note 2 and Greenlee \& Reitman supra note 2.

${ }^{38}$ At $\$ 16$, the consumer purchases the bundle and enjoys $\$ 1$ of surplus. A bundle priced at $\$ 17$ generates zero consumer surplus, so the consumer would instead purchase just $B$ for $\$ 5$ and enjoy $\$ 1$ of surplus.

${ }^{39}$ If customers purchase the goods in fixed proportions and there are constant returns to scale and perfect competition for $B$, any bundled pricing that induces consumers to take the bundle rather than purchase
} 
consumer who values $A$ at $\$ 15$ is worse off as a result of the bundling, but not because rival $B$ producers have been eliminated.) Indeed, suppose that there are many consumers who value $B$ alone at $\$ 5$ and place no value on $A$. They would continue to be served by producers solely of $B$. No exclusion of rivals occurs, yet the AMC safe harbor test is failed. $^{40}$

Third, a firm does not sacrifice profits today for increased future profit when it uses a loyalty discount to price discriminate. Rather, the firm is doing a better job of extracting rents today. Thus there are no losses to recoup, or the losses are recouped instantaneously on another product. The presence of calculated "losses" is due entirely to the accounting convention of the analyst, namely attributing a discount offered on the monopoly product as a cost of the competitive product. For these, the recoupment requirement (prong (2)) either makes no sense or is vacuous. ${ }^{41}$

Fourth, if the goal of a bundled loyalty discount actually is predation on product $B$, why "fund" the below-cost pricing with discounts given on another product? Why not just engage in predation on $B$ ? One motive may be that the firm employs a bundled loyalty discount in order to disguise predation. Alternatively, the loyalty program may be a less costly form of predation because the firm does a better job of extracting rents from its monopoly while it is preying in the competitive market. This latter explanation,

products separately will fail the first prong of the AMC test. Of course, the second prong could never be satisfied under these conditions (i.e., the firm could not recoup such losses). This suggests that the first prong is likely to condemn lots of behavior even when that behavior creates no antitrust harm.

${ }^{40}$ For additional discussion of how bundled discounts can be used by a firm to improve rent extraction, and how such firms can pass or fail the AMC test without necessarily harming competition, consult Patrick Greenlee, David Reitman \& David S. Sibley, An Antitrust Analysis of Bundled Loyalty Discounts, 26 INT’L J. INDUS. ORG. (forthcoming, 2008). The fact that the discount calculated in the AMC test often is not the appropriate opportunity cost suggests that the AMC test may in some settings make the reverse mistake. Namely, a firm may use a bundle discount to exclude rival $B$ producers (by denying them necessary scale) in which the standalone price for $A$ is not much higher than the program price for $A$. In such cases, the calculated discount for $A$ is not large, so that the marginal cost of $B$ plus the allocated discount may not exceed the price of $B$ (which itself may be inflated due to reduced competition).

${ }^{41}$ Dennis W. Carlton \& Michael Waldman, Safe Harbors for Quantity Discounts and BundLIng (U.S. Dep’t of Justice EAG Discussion Paper 08-1, 2008), Greenlee, Reitman \& Sibley, supra note 40, Nalebuff supra note 2, and the PeaceHealth opinion also make this point. 
however, is problematic in that we would expect to see a similar loyalty program offered by the firm even if it had no desire to prey in the second market. The motive would be better rent extraction in its current monopoly. ${ }^{42}$

Fifth, on prong (3), the primary question is what does it mean to establish that "the bundled discount or rebate program has had or is likely to have an adverse effect on competition.”? One possibility is that this language is part of the AMC recommendation in order to make the price/cost test prong a safe harbor. Namely, it does not suffice to prove that the defendant firm priced below cost as calculated according to prong (1) and that "recoupment” is likely, according to prong (2). The AMC approach requires a plaintiff to show that competition has been reduced. PeaceHealth points out that this requirement is tantamount to a full blown analysis of the case and, as such, does little to shorten the analysis.

\section{OUR APPROACH}

Rather than focusing on a price/cost test to establish that a defendant has engaged in predatory or anticompetitive conduct involving multiple products, our approach turns the emphasis to competitive effects. We move from a price/cost test whose logic is not always well-grounded to establishing the elements required in the economic theories of anticompetitive harm described in Section III. ${ }^{43}$ Recognizing that there frequently are

\footnotetext{
${ }^{42}$ One scenario in which funding predation in this manner would be better than a single product pricing strategy is if courts adopted a total cost predation standard for multiproduct bundles. That is, suppose it were legal to offer any pricing schedule for which the total outlay charged for a collection of goods always exceed the cost to produce that collection of goods. 3M advocated this legal approach in LePage's as did PeaceHealth in PeaceHealth. See also Timothy J. Muris, Comments on Antitrust Law, Economics, and Bundled Discounts, Submitted on Behalf of the United States Telecom Association (available at http://govinfo.library.unt.edu/amc/public_studies_fr28902/exclusionary_conduct.htm, July 15, 2005). Under such a regime, a firm with a monopoly (or more accurately, a product that earned a high margin) could price another good below cost whenever it was part of a bundle that included the monopoly product. The firm would pass such a screen, yet could (attempt to) prey upon single product rivals.

${ }^{43}$ One might ask whether there are better price costs tests than the AMC's to identify pricing that is so peculiar (is not consistent with profit maximization absent predation) as to merit antitrust scrutiny. Unfortunately the answer is no. In a multiproduct setting, there do not appear to be simple pricing rules governing the pricing across products. See, e.g., David Sibley \& Padmenabham Srinagesh, Multiproduct Nonlinear Pricing with Multiple Taste Characteristics, 28 RAND J. ECON. 684 (1977) who show that the
} 
pro-competitive rationales for non-linear pricing, we also permit defendant firms to make efficiency arguments for their pricing strategies.

In what follows, we adopt the terminology associated with tying. Namely, if a pricing strategy generates discounts on product(s) $A$ provided the consumer purchases enough of product(s) $B$, we refer to $A$ as a "tying good" and $B$ as the "competitive good" or "tied good." We use these terms as shorthand, and do not mean to imply that the approach below applies only to cases that meet legal definitions of tying.

\section{Required Elements}

1. There are economies of scale in the rival firm's production of the competitive (or tied) good, and the plaintiff could otherwise compete against the defendant.

Plaintiff firms may be excluded from a market due to competition on the merits, or due to anticompetitive strategies engaged in by rivals. A firm with high costs (and hence high prices) or low quality products should not be rescued by the courts when it gets excluded in the marketplace due to competition. For a pricing strategy to have an anticompetitive effect on rival firms, the strategy must alter the ability of rival firms to compete. This can be accomplished by denying a rival firm sales which otherwise would insure its survival or reduce its marginal costs.

Example 1. The rival firm has constant returns to scale technology — each unit costs the firm $c$ to produce. If the pricing strategy employed by the dominant firm does not increase $c$, then there can be no anticompetitive effect. In equilibrium, the pricing strategy may divert sales away from the rival firm, but the competitive constraint offered by the single product firm remains. In fact, the rival firm could lose all of its current customers (complete "exclusion”), but as long as there are no fixed costs, the possibility of purchasing from the rival firm (whose marginal cost is still $c$ ) maintains the current level of competition.

Example 2. The rival firm has constant marginal cost $c$ and a positive fixed cost $F$. If the prevailing equilibrium price for the competitive good is $p$, then the rival firm is excluded only if cannot sell at least $F /(p-c)$ units. If it cannot sell at least this amount when facing the nonlinear pricing strategy of the dominant firm, then the rival firm will

multi-product price schedule optimal for price discrimination may include goods for which incremental cost exceeds incremental revenue. 
exit. Thus, if $F$ is large, or the margin $p-c$ is small, the rival firm will need a large quantity of sales to participate in the market.

The presence of scale economies by itself is not enough to establish the possibility of competitive harm. If a firm can otherwise attain the necessary scale level, then a nonlinear pricing strategy that shifts some sales to the defendant firm will not induce exclusion, and there therefore should not be an antitrust violation. For there to be an anticompetitive effect, it must be the case that the plaintiff firm would have provided a more potent competitive constraint had the defendant firm not employed its nonlinear pricing strategy. As in the case of single product pricing, it may be difficult to determine what pricing strategy the defendant firm would otherwise employ. While recognizing that marginal cost pricing may not be the equilibrium strategy employed by the defendant (because products may be differentiated, for example), we recommend assuming that the plaintiff otherwise would compete against the defendant's product(s) priced at marginal cost. If the plaintiff can show that it could compete against such pricing, and that the defendant firm's pricing scheme denies it scale necessary to remain active in the market, then the plaintiff has satisfied this required element.

\section{The defendant firm has market power in the tying good}

When a firm uses linked pricing to exclude rival firms and reduce competition, it demonstrates that it possesses market power. Absent such market power, rival firms can continue to make acceptable offers to consumers and remain in the market, so competition would not be reduced in such cases. The questions then are whether establishing market power should be a requirement for proving an antitrust violation, and whether the defendant must already have market power prior to using linked pricing to exclude rival firms. When there are scale economies and firms can make customerspecific offers (i.e. price discriminate), a firm lacking ex ante market power can exclude by taking advantage of a lack of coordination among buyers. ${ }^{44}$ Given this possibility, we

\footnotetext{
${ }^{44}$ The details depend on how offers are made to consumers (public or private, sequential or simultaneous, etc), and whether buyers are final consumers. See Eric Rasmussen, J. Mark Ramseyer \& John S.Wiley, Naked Exclusion, 81 Am. Econ. Rev. 1137 (1991), Ilya Segal \& Michael D. Whinston, Naked Exclusion: Comment, 90 Am. Econ. Rev. 296 (2000), Chiara Fumagalli \& Massimo Motta, Exclusive Dealing and Entry, When Buyers Compete, 96 Am. Econ. ReV. 785 (2006), John Simpson \& Abraham L. Wickelgren,
} 
do not require a showing of ex ante market power. We are, however, concerned about incorrectly condemning behavior that turns out to be aggressive price competition. To accommodate this tradeoff, we propose requiring a plaintiff to establish ex ante market power if the case is brought before rival firms have exited. In such instances, there is a heightened danger of false positives-namely convicting firms that compete aggressively but do not exclude rivals. If they have exited, a plaintiff need only demonstrate that the defendant has ex post market power (i.e. after the defendant has employed its linked pricing strategy).

3. Does the price of the tied good increase for consumers that do not buy the tying good?

As discussed above, a non-linear multiproduct price schedule may be designed to extract rents in a monopoly product. In such cases, markups in a competitive product may serve the role of a flat fee or metering device for a monopoly product. If there are consumers that purchase only the tied product, it is natural to focus on the prices paid by such consumers because price discrimination or monopoly rent extraction is not a motive for such sales. If the price paid by such customers does not change following the introduction of a non-linear pricing scheme, then competition for the tied product has not been damaged. Consumers that purchase both goods may pay more, but this may reflect that the monopolist is doing a better job of extracting the available monopoly rents. If there are customers that purchase only the tied good, then a requirement for a case against a monopolist's use of a nonlinear pricing scheme is that the price paid for the competitive good by such customers increases, or is likely to increase. ${ }^{45}$

4. Is the rival firm still in the market? Has its marginal cost increased?

If no rival firms exit, and their marginal costs have not increased, then such firms continue to provide the same level of competitive constraint in the marketplace. While a multiproduct pricing scheme may reduce the sales made by rival firms and hence raise

Naked Exclusion, Efficient Breach, and Downstream Competition, 97 AM. ECON. REV. 1305 (2007), and the discussion in MiCHAEL D. Whinston, LECTURES ON ANTITRUST ECONOMICS (2008).

45 The focus here on the standalone price for $B$ differs from the approach presented in Greenlee, Reitman \& Sibley supra note 40 . They recommend focusing on the a la carte and loyalty program prices for $A$, and show that increases in the a la carte price are associated with consumer surplus reductions. In their base model, however, the $B$ market is perfectly competitive so there cannot be a competitive effect for consumers that purchase only $B$. 
rival firms' average cost, rival firms that remain in business with the same marginal cost can continue to provide the same offers to consumers. Since in such cases the dominant firm continues to face the same competition, a multiproduct pricing strategy that does not drive a rival firm completely out of business cannot harm the competitive process. Competition can be harmed without inducing complete exit, however, provided that denying scale causes a rival firm's marginal cost to increase. In such cases, the rival firm cannot profitably make the same low price offers to consumers, and the dominant firm may respond by raising price. One manner in which marginal cost could increase is if the pricing strategy denies access to the most efficient method of distribution. Another possibility is that in a dynamic setting the reduction in volume reduces the incentive for R\&D which, in turn, raises the firm's marginal cost in subsequent periods. ${ }^{46}$

With this, it follows that key questions for assessing potential anticompetitive effects of a linked pricing strategy are whether or not rival firms remain in business, and if they do, have their marginal costs increased? If rival firms remain in business and their marginal costs have not risen, then competition has not been harmed and there should be no antitrust violation. If rival firms remain in business, establishing an antitrust violation should require the plaintiff to demonstrate that as a result of the dominant firm's pricing strategy, they have lost sales that have caused their marginal costs to increase significantly. If firms have exited, or are on the brink of exit, they should demonstrate that the linked pricing schedule has caused them to lose scale necessary to remain in business.

\section{Potential Offsetting Efficiencies}

Our discussion in Section II described some rationales for linked pricing schedules other than excluding rival firms that cannot offer the same collection of goods. These included reducing costs by achieving economies of scale and price discrimination.

Just as efficiencies can counteract the harmful effects of a merger and should be included as a potential merger defense, efficiencies may affect competitive harms caused

\footnotetext{
${ }^{46}$ In most cases the answers to our third and fourth required elements will go in the same direction. In some cases, like the PeaceHealth case discussed in the next section, there will be no information for one of these two elements. When these two elements give contradictory answers, one will have to further investigate the causes of the price changes and/or exit, and the consequences of permitting the pricing strategy.
} 
by a nonlinear pricing strategy that disadvantages or excludes rival firms. As in merger review, the efficiencies should count only if they are not otherwise attainable, and the benefits from improved efficiency should be balanced against the competitive harms. Our approach differs from the "no economic sense" test which asks only if there is some benefit to the firm from the pricing strategy that is not related to excluding rival firms. Under that approach, a plaintiff would have to establish that but for the exclusionary effect, the challenged practice made "no economic sense." Thus, the existence of benefits would be enough for the defendant to prevail. In contrast, our approach, as in mergers, requires one to show that the benefits are not otherwise achievable, and that they outweigh the competitive harms. ${ }^{47}$

The rationales discussed in Section II also included price discrimination. While price discrimination can increase total surplus, its effects on total surplus are in general ambiguous. If in the course of price discriminating, a firm causes rival firms to exit an otherwise competitive market $(B)$, then in most cases this exclusion will allow the price discriminating firm to increase its price for $B$ (while it continues to price discriminate). Such a price increase is a competitive harm. Given this possibility, we recommend not recognizing price discrimination as a defense. If a price discriminating defendant can establish that exit by rival firms does not allow it to raise the price for $B$, then the $B$ market has not been adversely affected.

\section{DISCUSSION}

In this section we illustrate how our approach could be applied to LePage's and to PeaceHealth. We do not discuss in detail the factual record in either litigation, and instead focus on key questions that would have to be answered in order to determine whether a nonlinear multiproduct pricing schedule reduced competition. ${ }^{48}$

\footnotetext{
${ }^{47}$ For the "no economic sense" test, see Gregory J. Werden, Identifying Exclusionary Conduct Under Section 2: the 'No Economic Sense' Test, 73 AnTiTRUst L.J. 413 (2006). Timothy J. Brennan, Bundled Rebates as Exclusion, not Predation (unpublished manuscript, available at http://papers.ssrn.com/sol3/papers.cfm?abstract_id=992907, 2007) argues how the lack of balancing in the no economic sense test coupled with the frequent existence of some benefits (however small) leads one to conclude that nearly all unilateral behavior would be per se legal under that test.

${ }^{48}$ This discussion of LePage's relies heavily on Rubinfeld supra note 2.
} 
In LePage's, the plaintiff claimed that it lost large customers due to 3M's loyalty rebates, and as a result lost the benefit of economies of scale. LePage's, however, provided no testimony about such scale economies in the production or distribution of invisible tape. Furthermore, LePage’s provided no quantitative evidence about prices or costs, and did not claim that 3M had priced invisible tape, or some incremental volume of tape, below cost (even when discounts on other products were allocated to tape ${ }^{49}$ ). Finally, and perhaps most importantly, LePage’s assets did not vanish from the marketthey were purchased in May 2000 by Conros, a Toronto-based conglomerate. As part of Conros, LePage's continues to develop new tape products ${ }^{50}$ and according to a December 2007 press release:

Today, through its extensive distribution network, LePage’s provides branded and private label products to a number of large US retailers, including Office Depot, Wal-Mart, Kroger/Fred Meyer, HEB, Walgreen’s, Rite Aid, Publix, Wegman's and Food Lion, amongst several others. ${ }^{51}$

In terms of our approach, LePage's failed to provide evidence to support our first and third required elements--scale economies and observed/predicted price effects. ${ }^{52}$ At trial, 3M, with its Scotch tape brand and large market share, was shown to have market power in transparent tape, so the second required element would have been satisfied. While LePage’s claim would have failed under our approach due to a lack of evidence establishing (i) the importance of scale economies and (ii) observed/predicted price

\footnotetext{
49 Thus LePage's did not perform the price/cost test introduced in Ortho and advocated by the AMC.

${ }^{50}$ See, for example, Christina Campbell, Tale of the Tape: North America Competition, CANADIAN BUS. April 24, 2006, available at http://www.canadianbusiness.com/managing/strategy/article.jsp?content=20060424_76378_76378 (describes new LePage’s tape dispensers with palm guards and a brake system).

${ }^{51}$ Press Release, Pure Energy Visions Corporation, Pure Energy signs United States National Distribution Agreement with Conros Corporation, parent of LePage’s (December 24, 2007), available at http://www.usetdas.com/TDAS/NewsArticle.aspx?NewsID=10329

${ }^{52}$ With respect to price effects, Rubinfeld supra note 2 notes that it was undisputed that total output of transparent tape increased over the relevant time period. In addition, the public record does not include any information about how 3M's tape prices changed over time. With respect to scale economies, 3M argued that LePage's had been able to compete in the marketplace for a long time at a relatively small scale.
} 
increases, perhaps the most important shortcoming for its claim is that LePage's would have failed our fourth required element. LePage's remains in business and has many large U.S. retailer customers. Given this fact, LePage's would have had to demonstrate that its marginal cost had increased as a result of 3M's pricing strategy. LePage's did not establish this. Ultimately, 3M's discount pricing strategy may have caused LePage's to lose some large customers, but based on the available evidence the bundled rebates did not exclude LePage's or raise its marginal cost, and hence competition was not harmed.

In PeaceHealth, the parties were the only providers of hospital care in Lane County, Oregon. Both parties offered primary and secondary hospital care, while only PeaceHealth offered tertiary hospital care. The subject of this litigation was discounts that PeaceHealth offered to insurance companies that purchased exclusively from PeaceHealth. That is, PeaceHealth charged lower reimbursement rates (prices) for primary, secondary, and tertiary care to customers that did not use plaintiff McKenzieWilliamette Hospital (“McKenzie”). McKenzie’s claims against PeaceHealth included attempted monopolization, tying, and exclusive dealing.

PeaceHealth is noteworthy in that the court invited amicus briefs on the issue of whether a plaintiff in a bundled discount attempted monopolization case had to prove that the defendant's prices were below its costs. The opinion discusses several incremental price/cost tests, and ultimately finds that a plaintiff must establish prong (1) of the AMC test in order to prove that a defendant has engaged in predatory or anticompetitive conduct. Like us, the court finds that prong (2) of the AMC test (recoupment) makes no sense when the pricing strategy involves multiple products. Finally, the court finds prong (3) redundant-it is no different than the general requirement of a plaintiff to establish antitrust injury. Thus, the opinion focuses largely on the allocated discount price/cost test advocated by the AMC.

In terms of applying our required elements to PeaceHealth, there are scale economies in offering hospital care due, in part, to the medical equipment required to run a hospital. For purposes of assessing PeaceHealth's ability to exclude McKenzie, a key issue is how many customers (or insured lives) does a hospital like McKenzie need to cover its fixed costs. If just a small number of insurance company customers can cover these costs, then it would be difficult for PeaceHealth to drive McKenzie out of business 
by denying them scale. Prior to the bundling strategy, McKenzie argues that its prices were lower than PeaceHealth's, suggesting that McKenzie was providing some competitive discipline. Whether or not our first required element is established would depend on how significant these scale economies are.

A related point can be found in the PeaceHealth jury instruction about bundled discounts (based on LePage's):

Bundled price discounts may be anti-competitive if they are offered by a monopolist and substantially foreclose portions of the market to a competitor who does not provide an equally diverse group of services and who therefore cannot make a comparable offer. ${ }^{53}$

As we have discussed above, such discounts can harm competition only if they deny important scale to a rival firm. Thus, this instruction is consistent with our approach only if "substantially foreclose" is interpreted to mean something like "deny enough of the market to drive the competitor out of business or raise its marginal cost.” It is not enough to show that the rival firm was "foreclosed" from some customers, or that it was foreclosed from a substantial share of them. The key to establishing competitive harm is showing that the foreclosed business left insufficient scale for the firm to remain in business (or the denied scale led to increased marginal cost). How "substantial" such foreclosure must be will depend on the scale economies for the competitive product(s).

For our second required element, PeaceHealth performed $90 \%$ of the tertiary neonatal services and 93\% of the tertiary cardiovascular services in Lane County. Due to these high market shares, the fact that no other provider in Lane County offers tertiary services, as well as the presence of non-trivial entry barriers, it is reasonable to conclude that PeaceHealth has market power in the provision of tertiary hospital services in Lane County, so the second required element is satisfied.

The competition between PeaceHealth and McKenzie is for the 28 health insurance companies that operate in Lane County. If any of them purchase only primary and secondary hospital services, our approach would ask whether such customers pay

\footnotetext{
${ }^{53}$ PeaceHealth, at 11213. PeaceHealth argued that this instruction incorrectly states the law because any bundle discount that involves a monopoly product will meet this definition, without considering whether the defendant priced below cost, or whether the plaintiff was an equally efficient competitor.
} 
higher prices. Given that it is unlikely that any of these customers purchase only primary and secondary services, our third element is neither established nor contradicted.

Our fourth element checks to see if McKenzie has exited the market or if its marginal cost has increased due to reduced sales. McKenzie had suffered financial losses in the time period leading up to and including the litigation, but it did not exit. In fact, it merged with Triad Hospitals in 2003 and opened a new cardiac surgery suite and recovery unit in $2007 .^{54}$ For hospital services, it is unlikely that the cost of serving an additional patient (marginal cost) varies greatly for patient levels up to a hospital's bed capacity, so denying customers to McKenzie while not inducing McKenzie’s exit probably had no effect on McKenzie's ability to compete for new contracts. ${ }^{55}$ While it may have suffered losses over a period of time, McKenzie did not exit, and its marginal costs likely did not increase. ${ }^{56}$ If this is correct, then McKenzie would fail to establish our fourth required element.

There is no mention of any efficiency or price discrimination rationales for PeaceHealth's bundled discounts.

In sum, based on our reading of the opinions as well as some market facts (namely the continued existence of McKenzie-Williamette Hospital and LePage's tape facility as part of Conros), our approach would suggest that neither 3M nor PeaceHealth engaged in exclusionary conduct when they offered bundled discounts.

\footnotetext{
${ }^{54}$ Cardiac surgery is a tertiary service. Recruiting professionals to operate the facility took longer than expected. The first open heart surgery there (in March 2007) was performed by two surgeons whose practice is owned by PeaceHealth. See Tim Christie, Cardiac Surgery a Reality in Springfield, REgISTERGUARD, March 8, 2007, at B1.

${ }^{55}$ McKenzie in theory could have responded to lower revenues by selling some of its medical equipment in order to reduce its fixed costs. This could diminish McKenzie's ability to compete by reducing the quality of its offered services. We are not aware of any such cost cutting measures at McKenzie.

${ }^{56}$ It is unclear whether PeaceHealth abandoned the bundle discount while litigation was underway. Presumably, McKenzie could prevail on this required element only if it could be established that PeaceHealth had indeed stopped using a bundle discount, and that McKenzie would have exited had PeaceHealth maintained the bundle discount strategy.
} 


\section{CONCLUSION}

There has been much confusion over the proper approach to analyzing antitrust claims involving single product quantity discounts and multi-product nonlinear pricing schedules that may include ties or bundle discounts. Part of the confusion arises from a failure to distinguish price discrimination from pricing that harms competition by weakening the competitive constraint that rivals provide.

As a general matter, we find it useful to have a price cost test as a safe harbor for antitrust claims based on non-linear pricing of either single or multiple products. In constructing a safe harbor for single product cases, we can use the observation that it is unusual for incremental cost to exceed incremental price, though even this test is not perfect. In the case of multiple products, it is more difficult to construct a simple price cost test that does not have serious drawbacks. When there is bundle-to-bundle competition, testing to see whether the bundle's price exceeds cost is a reasonable possibility. When there is not bundle-to-bundle competition, the discount allocation rule proposed by the AMC has the drawback that it may fail to exonerate price discrimination that creates no competitive harm. Our view is that any price cost test will let through some conduct that can create antitrust harm and will similarly fail to exonerate some conduct that creates no such harm. We are willing to tolerate such mistakes because we think that offering discounts is generally pro-competitive. The fact that such price cost tests will fail to identify some anticompetitive behavior is the price one must pay for creating a business environment that does not chill price competition. Failing a safe harbor price cost test like the AMC test, however, should not cause one to condemn a pricing practice because our analysis shows that behavior that is not anticompetitive can easily flunk such tests. Using the economic theory of harm that underlies most models of anticompetitive exclusionary behavior, we propose an alternative set of tests as a safe harbor. For those who disagree with our view that price cost safe harbors, however imperfect, are desirable in this setting, we suggest they use our safe harbors only, while for those who agree with our views on the usefulness of price cost tests, we suggest using our tests as another set of safe harbors.

Our analysis has shown that an approach like the AMC's which tries to apply the theory underlying single product predation to settings with multiple products has several 
drawbacks. The approach we advocate here, either in addition to, or instead of, the discount allocation test, is to focus on competitive effects. A key ingredient in almost all anticompetitive theories that survive the one monopoly rent critique is the presence of scale economies. Our approach requires a plaintiff to establish that there are significant scale economies and that the challenged pricing scheme denies necessary scale to rival firms. If scale economies can still be achieved by the rival firms, then competition is not impaired and there should be no antitrust violation. Our second requirement is the presence of market power by the defendant. Our third requirement focuses on competitive effects and requires that prices have increased for customers that have no interest in the monopoly product. Finally we require that the competitive constraints provided by rivals have been significantly weakened either because the rivals have actually exited, are likely to do so in the near future, or because the rivals' marginal costs have risen. Unless all four requirements are met, there should be no antitrust liability. Since bundling and quantity discounts are ubiquitous even in the absence of significant market power, we know that there are underlying procompetitive justifications for them. Accordingly, one should be wary of over-zealous pursuit of antitrust liability for fear of chilling competition. 